\title{
Pelatihan Teknik Pencelupan dan Pengikatan Warna Benang Kepada Perajin Tenun Corak Insang di Kota Pontianak
}

\author{
Husna Amalya Melati ${ }^{*}$, Yudithya Ratih ${ }^{2}$, Metasari Kartika ${ }^{3}$ \\ ${ }^{1}$ Prodi Pendidikan Kimia, Fakultas Keguruan dan Ilmu Pendidikan, Universitas Tanjungpura \\ 2Jurusan Teknik Arsitektur, Politeknik Negeri Pontianak \\ ${ }^{3}$ Prodi Ekonomi Syari'ah, Fakultas Ekonomi dan Bisnis, Universitas Tanjungpura
}

\section{A R T I C L E I N F O}

\section{Article history:}

Received 20 May 2019

Received in revised form

10 June 2019

Accepted 30 July 2019

Available online 30 August 2019

\section{Kata Kunci:}

Tenun; corak Insang;

pencelupan; pengikatan;

zat warna; fixer

Keywords:

Gill weaving, dyeing, fixer

dye binding

\begin{abstract}
A B S T R A K
Pelatihan pencelupan dan pengikatan warna benang telah dilakukan kepada perajin tenun corak Insang di kota Pontianak. Kegiatan ini bertujuan untuk melatih perajin tenun agar dapat melakukan proses pencelupan dan pengikatan warna pada benang yang nantinya akan menghasilkan tenunan bermotif corak Insang. Pelatihan diikuti oleh perajin tenun yang tergabung dalam kelompok swadaya masyarakat yaitu KSM Mekar II dan KSM Pucuk Rebung. Sebanyak 12 orang dari anggota KSM yang mengikuti pelatihan ini. Peserta mendapat penjelasan materi berupa bahan yang digunakan dalam proses pencelupan meliputi zat warna dan penguncinya (fixer) serta praktek pencelupan dan pengikatan warna pada benang. Hasil pelatihan menunjukkan bahwa peserta telah mampu melakukan proses pencelupan dan pengikatan warna benang yang selanjutnya dianik sebagai benang lusi pada suri serta siap untuk ditenun menghasilkan tenun corak Insang.
\end{abstract}

\section{A B S T R A C T}

Yarn dyeing and binding training has been conducted for Insang weaving craftsmen in Pontianak. This activity aims to train the weaving craftsman to be able to do the process of dyeing and color binding on the yarn which will produce woven pattern motifs. The training was attended by weaving craftsmen who were incorporated in community self-help groups namely KSM Mekar II and KSM Pucuk Rebung. A total of 12 people from KSM members participated in this training. Participants received an explanation of the material in the form of materials used in the dyeing process, including dyes and fixers, as well as the practice of dyeing and binding to the thread. The results of the training show that participants have been able to do the process of dyeing and binding of the color of the thread which is then dianik as warp yarn in the suri and ready to be woven to produce weaving Insang patterns.

\footnotetext{
* Corresponding author.

E-mail addresses: h.a.melati@chem.edu.untan.ac.id (Husna Amalya Melati)
} 


\section{Pendahuluan}

Corak Insang adalah salah satu ikon khas kota Pontianak. Motif ini tergambar dalam berbagai atribut seperti seragam sekolah dan kantor, gedung, bus kota, dan beberapa titik fasilitas umum yang menggambarkan ciri khas kota Pontianak termasuk di dalamnya pada kain tenun. Tenun adalah salah satu kerajinan tangan yang mencirikan budaya lokal. Tenun dengan motif corak Insang baru dikembangkan oleh salah satu kumpulan perajin tenun di kota Pontianak dalam dua tahun terakhir ini yaitu 2016 dan 2017 hingga sekarang. Dua kelompok swadaya masyarakat (KSM) yang mengembangkan tenun corak Insang ini tergabung dalam KSM Mekar 2 dan KSM Pucuk Rebung.

Proses pembuatan kain tenun ini memiliki prosedur yang cukup kompleks. Dalam pengerjaannya membutuhkan ketelitian dan kesabaran yang cukup tinggi. [1]. Pekerjaan membuat kain tenun melalui beberapa tahap yang bersifat serial dan saling berkatan antara lain: kegiatan pertama adalah narraw atau memintal, kemudian dilanjutkan dengan proses nganik yaitu menggabungkan dari perumahan kolong benang ke anikan. Langkah selanjutnya adalah nattar yaitu kegiatan menggulung benang dengan menggunakan papan tandayan. Berikutnya adalah proses ngubung yaitu menghubungkan benang atau merapatkan benang dari tandayan ke suri. Langkah terakhir yaitu menenun. Oleh karena itu, apabila proses hulu ini belum selesai dilakukan maka proses berikutnya tidak dapat dilanjutkan [2]. Proses nganik merupakan pekerjaan paling rumit dan berpengaruh dalam proses produksi. Bahkan, di daerah Batu Layang ini, hanya ada dua orang saja yang memiliki kemampuan dalam proses nganik, hanya saja tidak begitu mampu dan produktif dalam mengerjakannya karena keterbatasan alat dan tenaga serta keahlian yang belum maksimal.

Di antara proses nganik dan nattar, ada proses hulu lainnya yang dilakukan untuk mendapatkan motif kain tenun corak Insang. Proses pembuatan motif corak Insang pada benang ini ada pada kegiatan mencelup dan mengikat warna Proses pewarnaan dapat dilakukan pada benang pakan maupun benang anikan sehingga pada saat ditenun nantinya akan diperoleh motif corak Insang. Namun, perajin tenun ini menghadapi kendala dalam proses pencelupan dan pengikatan warna yang masih tergantung dengan keahlian pihak lain. Hasil wawancara dengan perajin tenun, diperoleh informasi bahwa perajin tenun memesan benang anikan atau lusi yang sudah dicelup warna ke perajin tenun di kabupaten Sambas, baru kemudian benang anikan atau lusi yang dihasilkan digulung pada papan tandayan dan dihubung ke suri baru kemudian benang siap untuk ditenun oleh perajin tenun di kota Pontianak untuk menghasilkan motif corak Insang. Menurut perajin tenun, permasalahan yang dihadapi adalah tidak terdapat penenun yang memiliki kemampuan dalam proses pencelupan dan pengikatan warna pada benang.

Proses pencelupan dan pengikatan warna merupakan proses hulu dalam menenun sehingga apabila proses ini belum diselesaikan maka aktivitas menenun tidak dapat dilanjutkan. Proses pemesanan benang yang yang telah diwarna ini memerlukan waktu yang cukup lama hingga hitungan bulan, sehingga ketika perajin tenun mengalami kekosongan suri corak Insang, maka proses produksi tenun pun berhenti sampai suri selesai diisi benang anikan atau lusi motif corak Insang. Dalam satu lusi terdapat delapan lembar kain yang akan dihasilkan dengan ukuran $100 \times 180 \mathrm{~cm}$ perlembarnya. Proses pengerjaan tenun dapat dilakukan dalam 20-30 hari untuk tiap lusi. Jika seorang perajin tenun hanya memiliki satu lusi corak Insang, maka dalam 2-3 bulan berikutnya, perajin tenun tidak bisa melakukan proses produksi kain tenun. Akibatnya akan berpengaruh terhadap kapasitas produksi dan secara ekonomi berpengaruh terhadap pendapatan perajin.

Kerajinan tenun ini adalah salah satu warisan budaya lokal yang harus terus dikembangkan dan diharapkan produk ini menjadi salah satu produk unggulan daerah kota Pontianak. Motif atau corak tenun ini adalah corak Insang yang terinspirasi dari insang ikan dimana penduduk kota ini pada zaman dahulu kebanyakan bermata pencaharian sebagai nelayan. Motif adalah corak atau gambar pada kain yang membuat kain memiliki tampilan yang lebih menarik [3].Warna corak Insang yang dihasilkanpun belum beragam mengikuti trend warna kekinian. Warna yang ada masih didominasi oleh warna seperti coklat, merah marun dan hitam. Oleh karena proses pewarnaan belum dapat dilakukan secara mandiri sehingga hasil tenun yang dihasilkan menjadi terbatas dalam variasi warna. Warna merupakan salah satu komponen dari produk desain yang paling menonjol. Suatu objek dapat dilihat keindahannya melalui kehadiran warna. Warna yang berbeda menunjukan sifat, karakter, kebudayaan dan citra yang berbedabeda pula [4].

Hasil tenun menggunakan teknik gantung yang merupakan produksi KSM sebagai bentuk Usaha Kecil Menengah (UKM) ataupun Usaha Mikro Kecil Menengah (UMKM) juga dapat dijadikan produk ekspor. Salah satu keunggulan dari UKM dalam ekspor adalah mengandalkan keahlian tangan (hand made) dalam proses produksinya, seperti pada ukir kayu, kerajinan tenun, dan perhiasan [5]. Berdasarkan masalah yang dihadapi oleh perajin tenun, maka hal ini sejalan dengan program pengabdian pada masyarakat skim Program Pengembangan Produk Unggulan daerah (PPPUD) yang dapat bersinergi 
dengan perajin tenun sebagai mitra untuk mengembangkan produk melalui optimalisasi potensi budaya lokal dan potensi sumber daya manusia untuk mengembangkan produknya agar mudah dikenal, mudah diperoleh, dan memiliki daya saing yang tinggi di kancah lokal, nasional maupun internasional.

Beberapa tujuan dari Program Pengembangan Produk Unggulan Daerah (PPPUD) adalah meningkatkan pengetahuan dan keterampilan mitra dalam memacu pertumbuhan produk unggulan daerah dan meningkatkan kualitas dan kuantitas produk agar memiliki daya saing tinggi dengan tetap berlandas pada sifat unik yang mencirikan kedaerahannya. Oleh karena itu, salah satu permasalahan yang perlu diselesaikan adalah dengan memberikan pengetahuan dan pelatihan kepada perajin tenun dalam melakukan proses pencelupan warna benang agar terbentuk benang yang pada saat ditenun akan membentuk motif corak Insang. Akhir dari kegiatan ini adalah terdapatnya penenun yang mampu melakukan proses tersebut dan memberikan dampak terhadap peningkatan jumlah kapasitas produksi tenun dalam menjawab kebutuhan pasar.

\section{Metode}

Kegiatan pengabdian ini dilakukan di lokasi mitra penenun KSM Mekar II yang beralamat di Jalan Khatulistiwa Gang Sambas Jaya, kelurahan Batu Layang, kecamatan Pontianak Utara, Kota Pontianak. Jumlah penenun yang mengikuti kegiatan sebanyak 12 orang. Kegiatan yang dilaksanakan untuk melatih penenun agar dapat melakukan pewarnaan sesuai motif yang diinginkan dalam hal ini adalah corak Insang. Kegiatan dilaksanakan dalam satu hari dimulai dari proses penggulungan benang sampai dengan pewarnaan. Metode pendekatan dan prosedur kerja yang digunakan pada kegiatan ini adalah Sosialisasi Kegiatan, Pelatihan, Praktek, Pendampingan, dan Evaluasi.

Sosialisasi kegiatan merupakan bentuk pendekatan partisipatif dan instruksional yang dilakukan dalam upaya untuk mengenal karakteristik dari mitra maupun masyarakat sekitar sehingga akan memudahkan dalam mentransfer iptek yang diprogramkan melalui kunjungan rutin ke mitra dan melihat langsung rutinitas pekerjaan menenun. Selain itu pendekatan struktural dilakukan dengan menjalin hubungan dan berkoordinasi dengan perangkat RT/RW atau Kelurahan, termasuk pejabat di atasnya dalam program yang menjembatani hubungan lembaga terkait yang dibutuhkan mitra untuk mendukung implementasi program melalui pertemuan.

Pelatihan dilakukan dengan memberikan materi tentang bahan yang digunakan, proses/tahap persiapan mencelup benang, proses pencelupan dan pengikatan warna pada benang kepada mitra sampai seluruh materi tersampaikan dan dipahami. Untuk memperkuat pengetahuan, maka metode yang dilakukan berikutnya adalah Praktek dan Pendampingan. Kegiatan ini melibatkan peserta untuk dapat melakukan proses pencelupan dan pengikatan warna pada benang setelah mendapatkan materi pada pelatihan, kemudian mitra didampingi untuk melakukan praktek pada skala kecil sebagai upaya persiapan untuk melakukan produksi besar dan meluas. Evaluasi dilakukan untuk melihat tingkat keberhasilan dari kegiatan. Kegiatan dinyatakan berhasil ketika minimal 50\% penenun berhasil melakukan semua langkah yang dilakukan.

\section{Hasil dan pembahasan}

Pelatihan teknik pencelupan warna merupakan rangkaian kegiatan yang dilaksanakan dalam pengabdian pada masyarakat didasarkan pada kemampuan para perajin tenun yang selama ini belum dapat melakukan proses pencelupan benang sehingga dihasilkan benang yang sudah memiliki warna yang siap ditenun menghasilkan motif corak Insang. Hal ini menjadi sebuah permasalahan yang berdampak pada produk yang dihasilkan belum memenuhi permintaan pasar yang mulai meningkat. Permasalahan baik dari segi kecepatan produksi maupun jumlah produksinya.

Sebelum melaksanakan rangkaian kegiatan Pengabdian Kepada Masyarakay, maka perlu dilakukannya sosialisasi kegiatan termasuk di dalamnya Focus Group Discussion (FGD) dan Rencana Kerja Tindak Lanjut (RKTL) agar kegiatan dapat terencana dan berlangsung dengan baik sekaligus dirasakan oleh warga sebagai kegiatan yang penenun butuhkan. Sosialisasi kegiatan dilakukan di lokasi mitra, bertempat di rumah kediaman ibu Kurniati mitra KSM Mekar II di gang Sambas Jaya (Gambar 1).

Sosialisasi dilakukan sebagai bentuk metode pendekatan partisipasif dan instruksional dimana tim Penabdian Kepada Masyarakat memaparkan rancangan jadwal dan kegiatan yang akan dilaksanakan di tahun 2018. Melalui sosialisasi ini diharapkan mitra yaitu para penenun yang nantinya akan menjadi peserta dari beberapa kegiatan yang dirancang mengetahui bentuk-bentuk kegiatan yang akan dilakukan. Kegiatan yang dilakukan setelah sosialisasi adalah menggunakan metode Workshop integrative atau Focus Group Discussion (FGD). Agar hasil dari FGD bisa terwujud secara sistematis maka kegiatan Focus Group Discussions (FGD) yang dilakukan dibarengi dengan melakukan Rencana Kerja Tindak Lanjut (RKTL). 

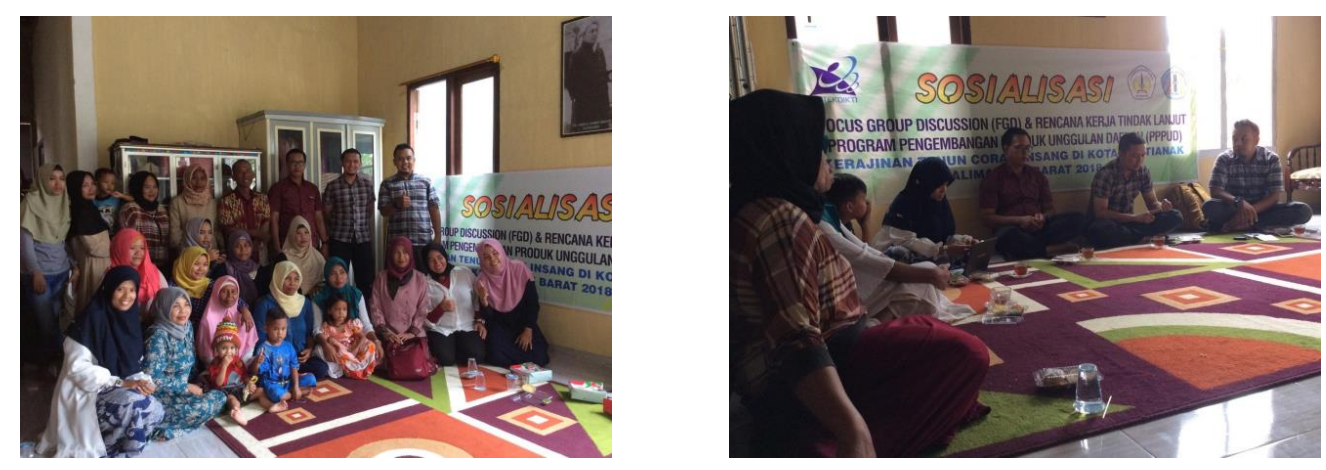

Gambar 1. Sosialisasi Kegiatan Pengabdian Kepada Masyarakat

Kegiatan FGD dan RKTL dilakukan pada hari yang sama dan tempat yang sama pula. Pelaksanaan Focus Group Discussions (FGD) dan Rencana Kerja Tindak Lanjut (RKTL) melibatkan mitra penenun, fasilitator, BKM, Korkot, tenaga ahli dari KOTAKU, maupun BDC. Hadir pula dalam kegiatan ini adalah Camat Pontianak Utara bapak Aulia Candra dan Lurah Batulayang bapak Mahsyar. Dalam FGD yang dilakukan, penenun diminta menyampaikan kendala yang dihadapi selama ini yang diharapkan dapat diurai dalam bentuk kegiatan. Beberapa yang disampaikan hampir sama dengan apa yang disampaikan pada saat penggalian masalah di koordinasi dengan mitra. Hasil dari kegiatan ini adalah penyepakatan bentuk kegiatan dan tanggal pelaksanaan masing-masing kegiatan. Dalam pertemuan ini juga diberikan arahan dari Badan Keswadayaan Masyarakat setempat untuk memanfaatkan kegiatan ini dalam rangka mengembangkan kerajinan tenun corak Insang. Oleh karena itu keikutsertaan yang sungguh-sungguh dari penenun untuk dapat mengikuti kegiatan pelatihan sangat diharapkan. Selanjutnya berdasarkan masalah terkait dengan proses pencelupa dan pengikatan warna benang, maka salah satu pelatihan yang dilakukan adalah pelatihan teknik pencelupan warna dan pengikatan warna pada benang.

Pelatihan ini dilakukan di lokasi mitra untuk memudahkan mitra mencapai lokasi. Pelatihan dimulai dengan penjelasan singkat mengenai bahan yang digunakan meliputi pewarna, garam pengikat warna (fixer), dan cara melakukan proses pencelupan dan pengikatan warna. Narasumber berasal dari tim pelaksana pengabdian dan dari dua orang mitra perajin tenun yang sebelumnya mendapatkan pelatihan singkat saat melakukan studi banding kegiatan proses pencelupan warna benang di Troso, kabupaten Jepara. Materi yang diberikan terkait dengan zat warna apa saja yang digunakan dalam pewarnaan benang.

Zat warna merupakan bahan kimia yang memiliki fungsi sebagai pewarna yang memiliki kemudahan melarut dalam air dan memiliki kemampuan afinitas terhadap serat [6]. Dalam pengertian yang lain, zat warna adalah semua zat yang memiliki warna dan berpotensi untuk dapat dicelupkan ke dalam serat tekstil dan mempunyai sifat yang tahan terhadap warna yang luntur (permanent) [7]. Jadi suatu zat dapat berlaku sebagai zat warna apabila zat tersebut memiliki gugus yang dapat menimbulkan warna (chromofor) dan zat tersebut mempunyai gugus yang dapat mempunyai afinitas terhadap serat tekstil auxsochrom. Definisi lain dari zat warna tekstil adalah suatu senyawa yang mengandung gugus kromofor dan auksokrom baik organik maupun anorganik sehingga kemudian memiliki daya untuk mewarnai bahan tekstil. Gugus kromofor merupakan gugus yang memunculkan warna sehingga molekul serat menjadi berwarna. Gugus yang mengaktivasi kinerja kromofor dan memberikan afinitas terhadap serat meliputi dua golongan yaitu golongan kation misalnya $\left(\mathrm{NH}_{2}\right)$ dan golongan anion $\left(\mathrm{COOH}\right.$ dan $\left.\mathrm{SO}_{3} \mathrm{H}\right)$ ini merupakan auksokrom. Zat warna memiliki syarat yaitu memiliki gugus yang dapat memunculkan warna dan dapat dilarutkan dalam air [8].

Setelah pemberian materi tentang pengetahuan bahan yang digunakan dalam proses pencelupan dan pengkitan warna pada benang, maka pelatihan dimulai dengan proses menggulung benang dan memintal benang (Gambar 2). Kemudian dilakukan pencelupan warna benang dimana sebelumnya, pintalan benang yang sudah disusun sedemikian rupa, diikat menggunakan tali rafia untuk membentuk model corak Insang (Gambar 3). Bagian yang ditutup tali rafia ini diharapkan tidak memiliki warna yang sama dengan celupan warna pertama. Teknik yang digunakan ini disebut teknik ikat celup atau seni ubar ikat. Melalui proses ini, benang diikat dengan tali rafia pada beberapa bagian tertentu, lalu dicelup dalam larutan zat pewarna tekstil. Benang akan menyerap zat pewarna tekstil kecuali bagian-bagian yang diikat dengan tali rafia. Hasilnya adalah terbentuk pola-pola seperti yang diinginkan yaitu pola corak Insang (Gambar 4). 


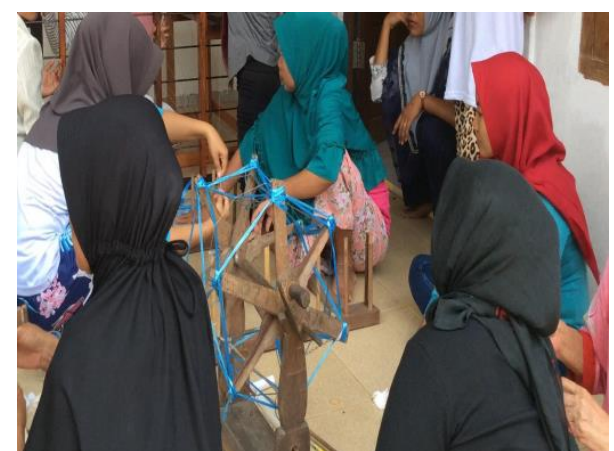

(a)

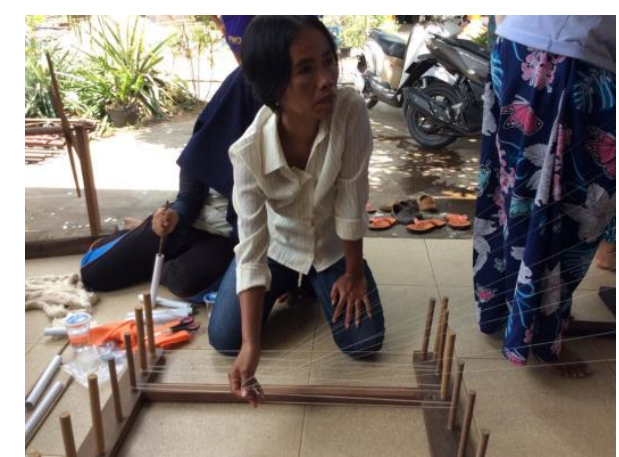

(b)

Gambar 2. Proses pemintalan \& penggulungan benang (a) penganikan benang (b)

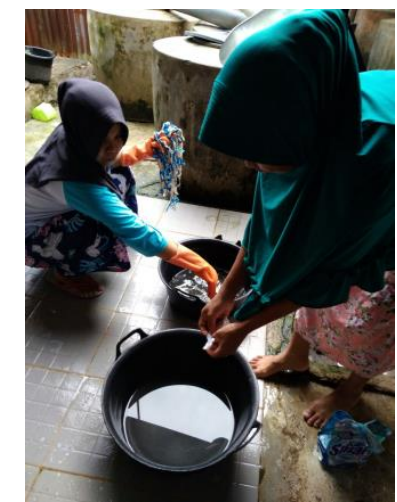

(a)

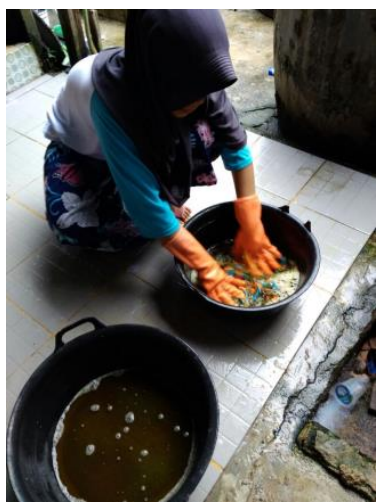

(b)

Gambar 3. Proses pembuatan larutan pewarna (a) pencelupan benang (b)

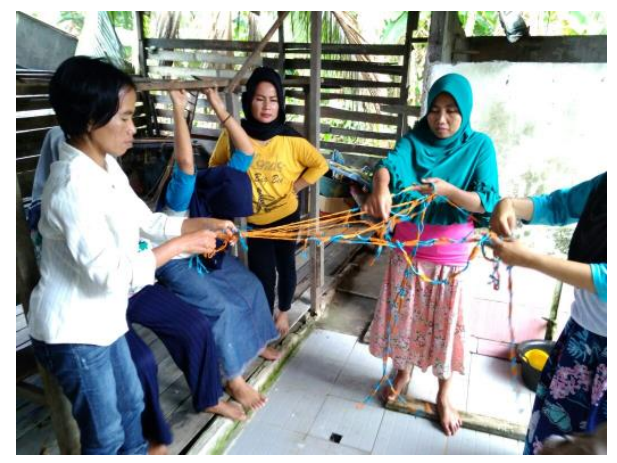

(a)

Gambar 4 Proses persiapan penjemuran benang (b) benang dilanjutkan pelepasan ikatan (b)

Untuk mencegah terserapnya zat warna maka dilakukan pengikatan agar zat warna tidak masuk ke dalam bagian-bagian yang diikat. Cara-cara lain untuk menghindari terserapnya zat warna adalah dengan menggunakan lilin, balok kayu, setik-setik jahitan, yang pada prinsipnya adalah bagian kain yang tertutupi tidak akan terkena zat warna [6]. Setelah dicelup, tali-tali dibuka kemudian diperolehlah dua warna yang berbeda dalam satu helai benang. Kemudian dilaukan proses fiksasi (fixer) untuk mengunci warna agar zat warna yang telah menempel dapat meresap pada bahan dan berikatan dengan kuat serta mencegah agar tidak mudah luntur. Kualitas warna sendiri perlu adanya fiksasi agar tidak luntur.

Proses pencelupan dapat diaplikasikan pada bahan fashion atau tekstil dalam bentuk benang serat, maupun kain. Pencelupan warna pada serat umumnya dilakukan untuk mendapatkan motif atau komposisi warna pada benang maupun kain sehingga diperoleh komposisi warna atau motif yang bukan berasal dari proses pencapan namun efek warna yang muncul dari campuran seratnya. Pencelupan pada benang diaplikasikan agar benang yang digunakan untuk kegiatan menenun menjadi terwarnai sesuai keinginan sehingga jika benang tersebut kemudian ditenun, maka akan diperoleh kain yang memiliki komponen corak dan warna tertentu. Warna atau corak ini diperoleh dari dari susunan dan persilangan 
benang lusi/anikan dan pakan. Pencelupan pada kain diaplikasikan untuk mewarnai kain agar diperoleh kain dengan warna yang sama dan merata pada seluruh kain. Corak atau motif tertentu dapat ditimbulkan dari proses pencelupan apabila benang atau kain memiliki komposisi yang berbeda dari dua jenis atau lebih serat tekstil. Hal ini disebabkan oleh daya dukung celup dan adanya efek dari warna yang berbedabeda oleh masing masing jenis serat terhadap setiap jenis zat warna yang digunakan.

Proses untuk memperkuat dan mempertajam warna agar tidak mudah luntur disebut dengan fiksasi [9]. Proses fiksasi memerlukan beberapa jenis bahan seperti tawas, kapur, jeruk, atau tunjung. Bahan-bahan tersebut memiliki karakteristik yang berbeda terhadap warna. Fiksasi/pembangkit adalah proses yang dilakukan setelah pencelupan zat pewarna, tujuannya dalah untuk penetralan dan menonjolkan zat pewarna yang sudah masuk ke dalam serat tekstil. Bahan pewarna yang dicelup secara langsung pada umumnya daya warnanya rendah, tetapi tidak tahan pada saat pencucian. Kelemahan tersebut dapat diperbaiki dengan fiksasi [10]. Pada pelatihan ini digunakan pengikat warna (fixer) berupa tawas dengan rumus kimia $\mathrm{KAl}\left(\mathrm{SO}_{4}\right)_{2}$ yang menghasilkan warna orange. Warna yang digunakan adalah warna asli dari zat pewarna tekstil karena perajin tenun belum menggunakan zat pewarna alami dalam kain tenunnya. Chadijah dan Alim menjelaskan "Warna asli adalah warna yang berasal dari warna-warna primer, sekunder, dan warna penghubung dan belum tercampur oleh warna hitam atau putih. Warnawarna asli bila dicampur putih kelihatan lebih terang" [4].

Dalam pendampingan praktek, tim dibantu oleh mitra yang menjadi fasilitator. Peserta terlihat antusias dan menikmati proses pelatihan karena perajin tenun merasa kegiatan ini sebagai sesuatu hal yang baru bagi mereka. Ditambah lagi dengan suasana yang santai, perajin tenun terlihat asyik mengamati prosesnya satu demi satu. Dari hasil pelaksanaan kegiatan pelatihan ini, diperoleh peningkatan kemampuan penenun dalam melakukan proses hulu sebelum menenun. Hasil observasi menunjukkan bahwa sebanyak 12 peserta telah mampu melakukan tahap penggulungan benang, 6 peserta mampu melakukan proses menganik, 12 peserta mampu melakukan tahap pengikatan benang, 6 peserta mampu melakukan pencampuran warna, 6 peserta mampu melakukan proses pencelupan warna, 12 peserta mampu melakukan tahap pelepasan ikatan. Oleh karena itu, kegiatan ini berdampak pada peningkatan jumlahpenenun yang memahami proses pencelupan warna pada benang dan mampu melakukan pencelupan dan pengikatan warna secara mandiri dengan peralatan rumah tangga sederhana.

\section{Simpulan dan saran}

Berdasarkan kegiatan pengabdian pada masyarakat yang telah dilakukan dapat disimpulkan bahwa kegiatan berhasil dilakukan dengan capaian $67 \%$ peserta pelatihan yaitu perajin tenun sudah dapat melakukan proses pencelupan warna dan pengikatan warna benang dengan motif corak Insang dengan lengkap. Diharapkan pada kegiatan berikutnya, perajin tenun dilatih untuk dapat menggunakan variasi fixer dalam mengunci warna, penggunaan jenis benang yang beragam dalam pencelupan warna, dan penggunaan pewarna alami.

\section{Daftar Rujukan}

Suhaeri, M. (2006). Tenun Songket Sambas Mati Suri? http://muhlissuhaeri.blogspot.co.id/2007/06/tenun-songket-sambas-mati-suri.html. (online).

Haryanto, J. (2014). Menilik Kerajinan Songket Sambas. http://baltyra.com/2014/08/15/menilikkerajinan-songket-sambas/. (online)

Hadisurya, Irma. (2011). Kamus Mode Indonesia. Jakarta: PT. Gramedia Pustaka Utama

Chodijah., Alim, Z. (2001). Desain mode tingkat dasar. Jakarta : Meutia Cipta Sarana

Tambunan, T. (1999). Perkembangan Industri Skala Kecil Di Indonesia. Jakarta: PT. Mutiara Sumber Widya.

Santoso, B., Mulyono,EWS. (2015). Penapisan Zat Warna Alam Golongan Anthocyanin dari Tanaman Sekitar Sebagai Indikator Asam Basa. Jurnal Fluida 11 (2) 1-8.

Sunarto. (2008). Teknik Pencelupan dan Pencapan. Direktorat Pembinaaan Sekolah Menengah Kejuruan, Direktorat Jenderal Manajemen Pendidikan Dasar dan Menengah. Departemen Pendidikan Nasional. Jakarta. 
Fitrihana., N (2007). Teknik Eksplorasi Pewarna Alam dari Tanaman di Sekitar Kita untuk Pencelupan Bahan Tekstil. Yogya : Kanisius

Lubis, H, Agusti, R.S, Suliyanthini, D. (2007). Pemberdayaan Ibu-Ibu di Babakan Madang Sentul dengan Pelatihan Membuat Produk Jumputan. Jurnal Sarwahita Volume 11 No. 2

Rini, Sancaya dkk. (2011). Pesona Warna Alam Indonesia. Jakarta: Kehati.

Sriatun, Sulhadi, Darsono, T, Bagus, R. (2017). Aplikasi Ekstrak Biji Binahong Merah Sebagai Pewarna Alam Ramah Lingkungan. Prosiding Seminar Nasional Fisika (e-journal) SNF2017. Vol. VI, Oktober 2017. https://doi.org/10.21009/03.SNF2017 